\title{
Role of somatostatin and its analogues in the treatment of acute and chronic pancreatitis
}

\author{
M W Büchler, M Binder, H Friess
}

\begin{abstract}
Acute pancreatitis is caused by the activation of digestive enzymes in the pancreas and a possible treatment, therefore, is the inhibition of enzyme secretion. This approach is somewhat controversial, however, as it is not clear whether pancreatic secretion continues to occur during the course of acute pancreatitis. Animal studies show an appreciable reduction of secretion in the inflamed pancreas, but studies in humans are not conclusive. The use of somatostatin or its analogue, octreotide, has been investigated in several clinical studies. A meta analysis of six individual studies in which somatostatin was given for acute pancreatitis showed that somatostatin significantly reduces mortality. A trial in patients with moderate to severe acute pancreatitis showed a lower rate (although not statistically significant) of complications in patients treated with $3 \times 200$ and $3 \times 500$ $\mu \mathrm{g} /$ day octreotide, compared with controls and patients receiving a lower dose of octreotide. A further study showed a significant reduction in patient controlled analgesics in patients treated with octreotide compared with controls. Pain is the important clinical symptom of chronic pancreatitis, possibly resulting from an increased intraductal pressure during secretion. The effect on pain of the inhibition of pancreatic secretion by octreotide has been investigated in two studies. One showed no significant reduction in pain after treatment with octreotide for three days. In the other, in which octreotide was used for three weeks, significantly less pain and analgesic use was recorded during octreotide treatment than during placebo. The most common complication of chronic pancreatitis is the formation of pseudocysts. There is some evidence that octreotide may be useful in their treatment.

(Gut 1994; supplement 3: S15-S19)
\end{abstract}

Department of

Visceral and

Transplantation

Surgery, University of

Berne, Switzerland

$\mathrm{M}$ W Büchler

$M$ Binder

H Friess

Correspondence to: Correspondence to:
Professor M W Büchler, Professor $M$ W Büchler, Transplantation Surgery, University of Berne, Inselspital, $\mathrm{CH}-3010$, Berne, Switzerland.

\section{Somatostatin in acute pancreatitis}

Acute interstitial pancreatitis is a mild and self limiting disease that responds well to conservative treatment. ${ }^{12}$ Therefore, it is associated with low complication and death rates. Ten to $20 \%$ of all patients with acute pancreatitis, however, develop peripancreatic and intrapancreatic necrosis. ${ }^{3}$ The release of toxic and vasoactive substances may lead to major systemic and metabolic complications followed by organ failure and death. ${ }^{4-6}$
At present, there is no specific and effective treatment available for acute pancreatitis. Therefore, treatment, especially of acute necrotising pancreatitis, consists of symptomatic treatment in an intensive care unit. ${ }^{1-8}$ The lack of specific treatment for acute pancreatitis is possibly one explanation why the death rates associated with severe acute necrotising pancreatitis are still high $(10-30 \%) .^{1-8}$

RATIONALE BEHIND THE INHIBITION OF PANCREATIC SECRETION IN PATIENTS WITH ACUTE PANCREATITIS

The pathogenic principle of acute pancreatitis is autodigestion, which is caused by the activation of digestive enzymes in the pancreas. $^{39}$ Therefore, one therapeutic concept for the treatment of acute pancreatitis is the inhibition of exocrine pancreatic enzyme secretion to slow down autodigestion of the pancreatic parenchyma. Before secretion inhibiting substances are adopted as a treatment of acute pancreatitis, however, it must be established whether pancreatic secretion still takes place during the course of this condition.

\section{EXOCRINE PANCREATIC SECRETION DURING} ACUTE PANCREATITIS

In animal studies ${ }^{1011}$ using various pancreatitis models it has been shown that basal and stimulated pancreatic secretion is reduced in rats or mice with acute pancreatitis. Data on secretion in the human pancreas during the inflammatory phase of acute pancreatitis are scarce.

Regan et al ${ }^{12}$ found increased pancreatic secretion of lipase and trypsin in two of three patients with acute pancreatitis who were seen in a clinical study on cimetidine and glucagon. Recently, we have reported that in six patients with mild or moderate acute pancreatitis, basal pancreatic secretion is similar to that in healthy subjects. ${ }^{13}$

After an attack of acute pancreatitis, the secretory capacity of the pancreas becomes temporarily insufficient. The degree of pancreatic insufficiency depends on the severity of the inflammatory process in the pancreas. ${ }^{14-17}$ It is, however, not known at what point during the course of acute pancreatitis this insufficiency occurs, and further studies are necessary to answer this important question.

In cases of acute pancreatitis after pancreatic transplantation, which might possibly be considered a model to study acute pancreatitis 
in humans, exocrine pancreatic function has been shown to be dependent on the degree of severity of the pancreatic inflammation. ${ }^{18}$ The more severe the transplantation pancreatitis, the less pancreatic secretion was present.

It is known that normal or food induced endogenous stimulation of the pancreas during inflammation worsens the course of acute pancreatitis and is absolutely contraindicated. In the basic treatment of the disease, endogenous stimulation is prevented by oral alimentary abstinence and continuous nasogastric suction. ${ }^{7}$ It is still controversial, however, whether basic treatment of acute pancreatitis should include the administration of secretion inhibiting substances. In a number of animal studies ${ }^{19-23}$ the effect of somatostatin and octreotide on the course of acute pancreatitis was investigated. There were some differences in both the experimental set up and the results of these studies. As some of the investigators gave secretion inhibiting substances before induction of acute pancreatitis and as secretion patterns during acute pancreatitis seem to differ between animals and humans, the results should not be transferred to the human situation. ${ }^{24}$

The pathophysiological prerequisites for the use of secretion inhibiting substances for acute pancreatitis have not been fully clarified. Animal data showed a considerable reduction of secretion of the inflamed pancreas. ${ }^{1011}$ The studies of human pancreatitis showed normal secretion function, ${ }^{13}$ whereas in transplantation pancreatitis, the amount of secretion depends on the degree of severity of the pancreatitis. ${ }^{18}$ There have been too few human studies, however, to permit any conclusions to be drawn. This controversial situation surely warrants putting the treatment principle 'inhibition of pancreatic secretion' to the clinical test.

\section{CLINICAL STUDIES WITH SOMATOSTATIN IN ACUTE PANCREATITIS}

Clinical studies with secretion inhibiting substances such as glucagon, calcitonin, and atropine ${ }^{25-28}$ and studies with protease inhibitors like aprotinin and gabexate mesilate, 2529 showed no positive effect on the course of acute pancreatitis.

TABLE I Review of somatostatin treatment in patients with acute pancreatitis. All six studies were prospective placebo controlled studies with a death rate $>5 \%$ in the placebo group. Meta analysis of these studies showed a significant reduction in mortality in patients with somatostatin treatment ${ }^{35}$

\begin{tabular}{|c|c|c|c|c|c|}
\hline Author & Placebo (n) & Death (n) & Somatostatin (n) & Death (n) & $p$ \\
\hline $\begin{array}{l}\text { Usadel et al }{ }^{31} \\
\text { Schöndube } \text { et al } \\
\text { Zuniga et al } \\
\text { Sanchez } \text { et al } \\
\text { Choi et al } \\
\text { D'Amico et al } \\
32\end{array}$ & $\begin{array}{r}41 \\
23 \\
5 \\
20 \\
36 \\
82\end{array}$ & $\begin{array}{l}7 \\
8 \\
1 \\
4 \\
2 \\
7\end{array}$ & $\begin{array}{r}36 \\
20 \\
7 \\
27 \\
35 \\
82\end{array}$ & $\begin{array}{l}4 \\
3 \\
2 \\
1 \\
1 \\
2\end{array}$ & $\begin{array}{l}\text { NS } \\
\text { NS } \\
\text { NS } \\
\text { NS } \\
\text { NS } \\
\text { NS }\end{array}$ \\
\hline Total & 207 & 29 & 207 & 13 & $\mathrm{p}<0.01$ \\
\hline
\end{tabular}

^Schöndube F, Klempa I, Baca I, Menzel J. Nekrotisierende Pankreatitis- ein Beitrag zur stadiengerechten operativen Therapie. Österreichische Gesellschaft für Chirurgie, Lanz, Juni 1987. †Zuniga J, Garcia L, Ortiz J, Pajares JM. Estudio de la eficacia del tratamiento con somatostatina en pancreatitis agudas graves. Libre de comunicantes de las XIV Jornadas Hispano-Francesas de Gastroenterologia y X Reunion de la Asociation Castellana del Aparto Digestivo, 39-40, Burgos, 1-3 Octubre, 1987. ¥Sanchez D, Sanchez A, Zurdo JR, Arriaza R, Chimpen V, Portugal J. Pancreatitis aguda. Estudio clinico y terapeutico. Valoracion de la somatostatin (resumen). Ann Med Inter (Madrid) 1988; (Suppl 3): 40.
TABLE II Score system in patients with acute pancreatitis. Fourteen typical complications of acute pancreatitis, including death within 90 days were defined. Individual scoring parameters were weighted according to the clinical relevance in acute pancreatitis. The sum of the parameters was calculated on admission to the hospital and in the follow up within 30 days 2938

\begin{tabular}{ll}
\hline & Points \\
\hline Organic complications & \\
Shock & 4 \\
Sepsis & 4 \\
Pulmonary insufficiency & 3 \\
Renal insufficiency & 3 \\
Peritonitis & 3 \\
Haemorrhage & 3 \\
Ileus/subileus & 1 \\
Metabolic complications & 2 \\
Hypocalcaemia & 2 \\
Clotting disorders & 1 \\
Jaundice & 1 \\
Hyperglycaemia & 1 \\
Encephalopathy & 1 \\
Metabolic acidosis & \\
Death: 30 points (sum of all complications +1$)$ & \\
\hline
\end{tabular}

The first clinical study in which somatostatin was used for acute pancreatitis was published by Limberg and Kommerell in $1980 .{ }^{30}$ In a study of 14 patients they found 'an impressive clinical improvement in all patients'. This promising finding was tested in several controlled clinical studies. ${ }^{31-34}$ Although the patients treated with somatostatin showed a lower complication rate, death rate, and better biochemical parameters, statistical significance could not be established. In a meta analysis ${ }^{35}$ Carballo analysed the statistical quality of six randomised studies in which somatostatin was given for acute pancreatitis (Table I). In these individual studies no statistically significant effect on mortality could be proved. The meta analysis showed that, taking these six studies together, somatostatin significantly reduces the mortality associated with acute pancreatitis $(p<0.01$, Table I). Further prospective studies with somatostatin or its analogues are necessary, ${ }^{36}$ using sufficient numbers of patients.

\section{OCTREOTIDE IN ACUTE PANCREATITIS}

We evaluated the effect of octreotide on the course of severe acute pancreatitis in an open prospective phase I/II study. Only patients with moderate to severe pancreatitis were included in the study. After randomisation eight patients in each group were treated either with $3 \times 100 \mu \mathrm{g} /$ day, $3 \times 200 \mu \mathrm{g} /$ day or $3 \times 500$ $\mu \mathrm{g} /$ day octreotide subcutaneously for 10 days. Complications were assessed according to a standard scoring system ${ }^{29}$ (Table II) on admission to hospital and in the follow up within 30 days.

A positive difference between the admission score and the follow up score was regarded as a positive treatment effect. A total of 24 patients (10 male, 14 female, median age 58 years, median Ranson score 3.4) were treated with octreotide. One hundred and eight patients with acute pancreatitis (median Ranson score 3.7) served as a historic control group. ${ }^{29}$ The three octreotide groups and the control group were comparable with regard to age, sex, and severity of pancreatitis. Two $(8 \cdot 3 \%)$ of the octreotide treated patients died because of 
TABLE III Results of a unicentric prospective trial analysing the effect of three different doses of octreotide in patients with moderate to severe acute pancreatitis. The sum of acute pancreatitis relevant complications was calculated according to the definition in Table II on admission to the hospital and in the follow up within 30 days. $A$ positive difference represents a reduction of complications ${ }^{38}$

\begin{tabular}{llll}
\hline & Admission & Follow up & Difference \\
\hline Control & $5 \cdot 1$ & $7 \cdot 2$ & $-2 \cdot 1$ \\
$3 \times 100 \mu \mathrm{g}$ & $5 \cdot 6$ & $7 \cdot 1$ & $-1 \cdot 5$ \\
$3 \times 200 \mu \mathrm{g}$ & $5 \cdot 0$ & $2 \cdot 0$ & $+3 \cdot 0$ \\
$3 \times 500 \mu \mathrm{g}$ & $5 \cdot 8$ & $4 \cdot 8$ & $+1 \cdot 0$ \\
\hline
\end{tabular}

septic complications, which are still the most important causes of fatal outcome in human acute pancreatitis. ${ }^{37}$ There was a lower rate of complications in the groups treated with $3 \times 200$ and $3 \times 500 \mu \mathrm{g} /$ day octreotide than in the low dose octreotide and control groups (Table III). Because of the small number of patients the results have no statistical power. ${ }^{38}$

Octreotide plasma concentrations were measured with a specific radioimmunoassay and the Figure shows that they differed with regard to the dose given. Shock had no influence on the plasma concentration of octreotide.

In a further controlled study ${ }^{39} 19$ patients with acute pancreatitis were either treated with octreotide $(250 \mu \mathrm{g}$ subcutaneously, followed by $0.5 \mu \mathrm{g} / \mathrm{kg} / \mathrm{hour}$ ) or acted as controls. A significant reduction of the patient controlled consumption of analgesics was seen in octreotide treated patients compared with the controls $(p<0.05)$. Unfortunately, only patients with mild pancreatitis were admitted to this study, so that no conclusion can be made as to the differences in mortality between the octreotide and control groups. The possible analgesic effect of somatostatin in human acute pancreatitis has been confirmed in an Italian multicentre study. ${ }^{32}$

\section{PERSPECTIVES}

The mechanism by which somatostatin and its analogue octreotide act on acute pancreatitis has been considered to be inhibition of

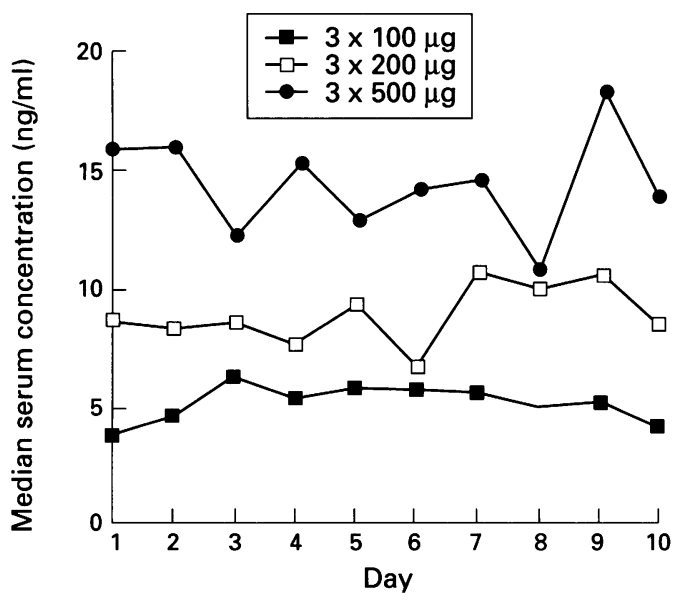

Median serum concentration of octreotide in eight patients with severe acute pancreatitis. Octreotide $(3 \times 100 \mu \mathrm{g}$, $3 \times 200 \mu g, 3 \times 500 \mu g$ ) was given three times daily by subcutaneous injection for 10 days. The concentration of octreotide was measured with a specific radioimmunoassay. exocrine pancreatic function. Another explanation stems from the notion of a 'cytoprotective' effect of these substances. ${ }^{40-42}$ Schwedes $e t$ al $^{21}$ induced acute pancreatitis in dogs by injecting bile into the ductal system and found considerably less macroscopic and histological damage to the pancreas in animals treated with somatostatin than in the control group. The inhibitory effect of somatostatin on pancreatic secretion could not, however, be solely responsible for these differences. The authors assumed that somatostatin had a further direct protective effect on the pancreatic acinar cells.

In a double blind randomised clinical study, Choi et al ${ }^{33}$ saw a 'beneficial local effect' of somatostatin and that 'local inflammation was suppressed by somatostatin treatment'. Jenkins et $a l^{43}$ studied the effect of somatostatin and octreotide on the reticuloendothelial system in rats with acute pancreatitis and recorded increased hepatic and splenic reticuloendothelial system activity. Furthermore, octreotide was shown to significantly reduce endotoxin concentrations in the serum. In patients with cirrhosis of the liver and portal hypertension octreotide increased the phagocyte activity of the monocytes. ${ }^{44}$ According to Jenkins et al these results confirmed the cytoprotective effect of somatostatin and octreotide, which was originally postulated by Zsabo and Usadel. ${ }^{4041}$ Overall the cytoprotective effect of octreotide seems to be a new and interesting feature in inflammatory disorders. Further studies are necessary to investigate the influence of this effect in acute pancreatitis.

To date, no conclusive evidence is available for or against the use of somatostatin or octreotide in acute pancreatitis. The efficacy of somatostatin or octreotide can only be proved in clinical studies. The results of a randomised, controlled multicentre trial with a study population of 300 patients, which is currently being started, will provide useful information on the future use of these substances for medical treatment of acute pancreatitis.

\section{Chronic pancreatitis}

Chronic pancreatitis is defined as the irreversible focal, segmental, or diffuse destruction of the pancreatic parenchyma. Four hypothetical concepts have been posed to explain the pathogenic mechanisms of chronic pancreatitis.

According to Sarles, ${ }^{45}$ the chronic intake of alcohol, which is the most important aetiological factor of chronic pancreatitis, causes a change in pancreatic secretion with the formation of protein plugs and calcifications in the ductal system of the pancreas. A second hypothesis is based on the notion of spontaneous activation of intraparenchymal proteases, which leads to small areas of pancreatic necrosis followed by fibrosis. ${ }^{46}$

Furthermore, oxidative stress caused by increased levels of free radicals and disorders in hepatic detoxification ${ }^{47}$ and direct toxic effects of ethanol on pancreatic acinar and ductal cells are considered to play an important part in the pathophysiology of chronic pancreatitis. ${ }^{48}$ 
TABLE IV Symptoms and complications in 223 patients with chronic pancreatitis ${ }^{49}$

\begin{tabular}{ll}
\hline & Frequency (\%) \\
\hline Pain & 90 \\
Pancreatic insufficiency & 19 \\
Diabetes mellitus & 17 \\
$\quad$ Insulin dependent & 20 \\
$\quad$ Non-insulin dependent & \\
Pseudocysts & 43 \\
$\quad<6 \mathrm{~cm}$ & 12 \\
$>6 \mathrm{~cm}$ & 2 \\
Ascites & 6 \\
Stenosis of duodenum & 4 \\
Portal hypertension & \\
\hline
\end{tabular}

The most recent classification of chronic pancreatitis $^{45}$ distinguishes between four groups: (a) lithogenic pancreatitis, the largest group, which consists of five subgroups according to the type of stone; (b) obstructive pancreatitis, which is caused by obstruction of the pancreatic ducts before the onset of pancreatitis; (c) inflammatory pancreatitis; (d) pancreatic fibrosis.

Pain, either intermittent or persistent, is the major clinical symptom of chronic pancreatitis, even in the early stage of the disease. As the disease progresses, the characteristic triad of symptoms develops with pain, maldigestion, and diabetes mellitus. Roughly $40 \%$ of patients with chronic pancreatitis develop complications $^{49}$ (Table IV).

Treatment for chronic pancreatitis includes: elimination of the cause: alcohol abuse; treatment of pain; treatment of pancreatic insufficiency; treatment of complications.

\section{MANAGEMENT OF PAIN ASSOCIATED WITH}

CHRONIC PANCREATITIS BY OCTREOTIDE

Analgesics are usually indispensable in the treatment of the pain associated with chronic pancreatitis, although the possible polytoxicomania in these patients makes their use undesirable. An alternative method of pain treatment is based on the theory that pain may result from increased intraductal pressure during stimulation of pancreatic secretion. ${ }^{46}$ Therefore, the inhibition of pancreatic secretion should influence the chronic pain syndrome in patients with chronic pancreatitis. Enzyme substances given in high doses improves exocrine pancreatic insufficiency and reduces the pain in some patients, presumably as a result of feedback regulation. ${ }^{46}$

The effect of direct inhibition of pancreatic secretion on pain associated with chronic pancreatitis was investigated in two independent studies. Malfertheiner et al $^{50}$ in a double blind randomised crossover study of 10 patients investigated the influence of $3 \times 250 \mu \mathrm{g} /$ day subcutaneously octreotide on pain. All patients received either octreotide treatment or placebo for three days in random order at two day intervals. The investigators saw no significant pain reduction after octreotide.

Another study group ${ }^{51}$ conducted a similar investigation in six patients with chronic pancreatitis and recurrent abdominal pain. The patients received $3 \times 100 \mu \mathrm{g} /$ day subcutaneously octreotide for three weeks and placebo for one week. During the octreotide treatment there was less pain and analgesic use recorded than during treatment with placebo $(p<0.05)$. The authors concluded that octreotide provides relief of chronic abdominal pain associated with chronic pancreatitis in some, but not in all patients.

The discrepancy in these two clinical studies is difficult to explain. It might be that the different treatment times (three days compared with three weeks) had an effect on the success of the treatment. The results of a multicentre study carried out in the US, which should soon be available, are expected to provide further information on the use of octreotide to treat pain associated with chronic pancreatitis.

\section{TREATMENT OF COMPLICATIONS ASSOCIATED WITH CHRONIC PANCREATITIS}

The most common complication associated with chronic pancreatitis is the formation of intra or extrapancreatic pseudocysts. Small pseudocysts $(2-6 \mathrm{~cm})$ usually produce no clinical symptoms, while larger cysts $(>6 \mathrm{~cm})$ are often very painful and can cause haemorrhage, abscess, stenosis of the pancreatic duct, and bile duct obstruction, as well as stenosis of the duodenum. ${ }^{4649}$ Various authors have pointed out the beneficial effect of octreotide in the treatment of pancreatic pseudocysts. Gullo and Barbara ${ }^{52}$ treated seven patients with chronic pancreatitis who had developed pancreatic pseudocysts with $3 \times 100 \mu \mathrm{g} /$ day octreotide for two weeks. Four of seven patients responded immediately to the octreotide treatment and the mean size of the pseudocysts decreased by $42 \%$. Furthermore, all four patients were completely pain free.

Morali et $a l^{53}$ reported on an infected pancreatic pseudocyst in which percutaneous evacuation was not successful. After one week of treatment with $300 \mu \mathrm{g} /$ day octreotide, the cyst shrunk from $8 \mathrm{~cm}$ to $1 \mathrm{~cm}$ and drainage secretion decreased from $200 \mathrm{ml} /$ day to 30 $\mathrm{ml} /$ day. Similar results in the treatment of pancreatic pseudocysts that had persisted after percutaneous drainage were reported by Barkin et $\mathrm{al}^{54}$ in a total of three patients.

In some cases, octreotide has also been reported to successfully treat ascites resulting from pancreatic disorders. ${ }^{55} 56$

\section{PERSPECTIVES}

The new approach to the treatment of complications associated with chronic pancreatitis by somatostatin analogues is encouraging. Octreotide, a potent inhibitor of exocrine basal and stimulated pancreatic secretion, has been successfully used to prevent postoperative complications after pancreatic surgery ${ }^{57}$ and to treat pancreatic fistulae. ${ }^{58}$ The treatment of pancreatic pseudocysts and ascites with octreotide is the logical extension of this management concept.

Further studies are required, however, to find out if octreotide or the combination of percutaneous catheter drainage and octreotide treatment can reduce the rate of surgery necessary for symptomatic pseudocysts. 
It has been suggested that the damaged pancreas reacts less effectively to the inhibitory effect of somatostatin on pancreatic exocrine secretion. ${ }^{59}$ The positive results, ${ }^{52-58}$ however, of octreotide in patients with chronic pancreatitis show that secretion inhibiting substances may be a new treatment concept in such patients.

1 Beger HG, Büchler M, eds. Acute pancreatitis. Research and clinical management. Berlin, Heidelberg, New York: Springer-Verlag, 1987.

2 Büchler $M$. Objectification of the severity of acute pancreatitis. Hepatogastroenterology 1991; 38: 101-8.

3 Becker V. Pathological anatomy and pathogenesis of acute pancreatitis. World ₹ Surg 1981; 5: 303-13.

4 Beger HG, Bittner R, Block S, Büchler $M$. Bacterial contamination of pancreatic necrosis. A prospective clinical study. Gastroenterology 1986; 91: 433-8.

$5 \mathrm{McFadden}$ DW. Organ failure and multiple organ failure in pancreatitis. Pancreas 1991; 6: 37-43.

6 Büchler M, Malfertheiner P, Schädlich H, Nevalainen TJ, Frie $\beta$ H, Beger HG. Role of phospholipase A2 in human acute pancreatitis. Gastroenterology 1989; 97: 1521-6.

7 Hotz J. Konservative Therapie der akuten Pankreatitis. Chir Gastroenterol 1988; 4: 59-65.

8 Banks PA. Predictors of severity in acute pancreatitis. Pancreas 1991; 6: 7-12.

9 Steer ML, Meldolesi J. Pathogenesis of acute pancreatitis. Ann Rev Med 1988; 39: 95-105.

10 Niederau C, Niederau M, Luthen R, Strohmeyer G, Ferell $\mathrm{LD}$, Grendell JH. Pancreatic exocrine secretion in acute experimental pancreatitis. Gastroenterology 1990; 9: 1120-7.

11 Evander A, Hederström E, Hultberg B, Ihse I. Exocrine pancreatic secretion in acute experimental pancreatitis. Digestion 1982; 24: 159-67.

12 Regan PT, Malagelada JR, Go VLW, Wolf AM, DiMagno EP. A prospective study of the antisecretory effects of cimetidine and glucagon in human acute pancreatitis. Mayo Clin Proc 1981; 56: 499-503.

13 Domínguez-Muńoz JE, Pieramico $O$, Büchler $M$, Malfertheiner P. Interdigestive exocrine pancreatic function and motilin release in the early phase of acute function and motilin release in the

14 Büchler M, Hauke A, Malfertheiner P. Follow-up after acute pancreatitis: Morphology and function. In: Beger HG, Büchler M, eds. Acute pancreatitis.
Heidelberg, New York; Springer-Verlag, 1987; 366-74.

15 Gullo L, Sarles H, Mott CB. Functional investigation of the exocrine pancreas following acute pancreatitis. Rend Gastroenterol 1972; 4: 18-21.

16 Mitchell CJ, Playforth MJ, Kelleher J, McMahon MJ. Functional recovery of the exocrine pancreas after acute pancreatitis. Scand $\mathcal{F}$ Gastroenterol 1983; 18: 5-8.

17 Angelini G, Pederzoli P, Caliari S. Long-term outcome of acute necrohemorrhagic pancreatitis. Digestion 1984; 30: 131-7.

18 Pfeffer F, Büsing M, Becker HD, Hopt UT. Gibt es eine akute exokrine Pankreasinsuffizienz? Lang Arch Chir Suppl Chir Forum 1993: 227-31.

19 Mann NS, Mauch MJ, Barnett R. Intraductal somatostatin protects against experimentally induced pancreatitis. Gastroenterology 1980; 78: 1217

20 Zhu ZH, Holt S, El-Lbishi MS, Grady T, Taylor TV, Powers RE. A somatostatin analogue is protective agains retrograde bile salt-induced pancreatitis in the rat. Pancreas 1991; 6: 609-13.

21 Schwedes U, Althoff PH, Klempa I, Leuschner U, Mothes L, Raptis S, et al. Effect of somatostatin on bile-induced acute hemorrhagic pancreatitis in the dog. Horm Metab Res 1979; 11: 655-61.

22 Lankisch PG, Koop H, Winckler K, Fölsch UR, Creutzfeldt W. Somatostatin therapy of acute experimental pancreatiW. Somatostatin therapy
tis. Gut $1977 ; 18: 713-6$.

23 Schlarman DE, Beinfeld MC, Andrus C, Kaminski DL Effects of somatostatin on acute canine experimental pancreatitis. Int $\mathcal{F}$ Pancreatol 1987; 2: 247-55.

24 Steinberg WM, Schlesselman SE. Treatment of acute pancreatitis. Comparison of animal and human studies. Gastroenterology 1987; 93: 1420-7.

25 MRC multicentric trial of glucagon and aprotinin. Lancet 1977; ii: $632-5$.

26 Cameron JL, Mehigan D, Zuidema CD. Evaluation of atropine in acute pancreatitis. Surg Gynecol Obstet 1979; 148: $206-8$.

27 Goebell H, Amman R, Herfarth C. A double-blind trial of glucagon treatment of acute pancreatitis. Scand $\mathcal{F}$ Gastroenterol 1979; 14: 881-9.

28 Broe RJ, Zinner MJ, Cameron JL. A clinical trial of cimetidine in acute pancreatitis. Surg Gynecol Obstet 1982 154: $13-6$.

29 Büchler M, Malfertheiner P, Uhl W, et al. Gabexate Mesilate in human acute pancreatitis. Gastroenterology 1993; 104: 1165-70.

30 Limberg B, Kommerell B. Treatment of acute pancreatitis with somatostatin. N Engl f Med 1980; 79: 284.
31 Usadel KH, Uberla KK, Leuschner U. Treatment of acute pancreatitis with somatostatin: Results of the multicenter double-blind trial (APTS-Study). Dig Dis Sci 1985; 30: 992.

32 D'Amico D, Favia G, Biasiato R, et al. The use of somatostatin in acute pancreatitis - results of a multicenter trial. Hepatogastroenterology 1990; 37: 92-8.

33 Choi TK, Mok F, Zhan WH, Fan ST, Lai ECS, Wong J. Somatostatin in the treatment of acute pancreatitis: a prospective randomized controlled trial. Gut 1989; 30 223-7.

34 Gjorup I, Roikjaer O, Anderson B, et al. A double-blind multicentric trial of somatostatin in the treatment of acute pancreatitis. Surg Gynecol Obstet 1992; 175: 397-400.

35 Carballo F, Dominguez E, Fernández-Calvet L, MartinezPancorbo C, García A, De la Morena J. Is somatostatin useful in the treatment of acute pancreatitis? - A metaanalysis. Digestion 1991; 49: 12-3.

36 Baxter JN, Imrie CW, McKay CJ. Acute pancreatitis and octreotide. Lancet 1991; 338: 389.

37 Büchler M, Malfertheiner P, Friess $\mathrm{H}$, et al. Human pancreatic tissue concentration of bacterial antibiotics. Gastroenterology 1992; 103: 1902-8.

38 Binder M, Büchler M, Uhl W, Friess H, Dennler HJ, Beger HG. Octreotide in the treatment of acute pancreatitis: results of an unicentric prospective trial with three different octreotide dosages. Lang Arch Chir Suppl Chir Forum 1993: 233-8.

39 Beechey-Newman N, Lee W, Wilkinson M, Grogono J McPerson GAD. Treatment with high dose octreotide improves the clinical course of acute pancreatitis. Gut 1991; 32: 558 .

40 Zsabo S, Usadel KH. Cytoprotection-organoprotection by somatostatin: gastric and hepatic lesions. Experientia 1982; 38: $254-6$.

41 Zsabo S. Somatostatin stimulates clearance and hepatic uptake of colloidal carbon in the rat. Life Sci 1983; 33. $1975-80$.

42 Usadel KH, Kessler H, Rohr G, Kusterer K, Palitzsch KD, Schwedes U. Cytoprotective properties of somatostatins Klin Wochenschr 1986; 64 (suppl VII): 59-63.

43 Jenkins SA, Barter JN, Day DW, Al-Sumidaie AM, Leinste SJ, Shields R. The effects of somatostatin and SMS 201995 on experimentally-induced pancreatitis and endotoxaemia in rats and on monocyte activity in patients with cirrhosis and portal hypertension. Klin Wochenschr 1986; 64: $100-6$.

44 Jenkins SA, Ellenbogen S, Day DW, Roberts N, Barter JN. Effects of SMS 201-995 on reticuloendothelial system (RES) activity in rats with acute pancreatitis. Gut 1987; 28: A1381.

45 Sarles H. Definitions and classification of pancreatitis. Pancreas 1991; 6: 470-4.

46 Klöppel G, Maillet B. The morphologic basis for the evolution of acute pancreatitis into chronic pancreatitis. In: Beger HG, Büchler M, Ditschuneit $H$, Malfertheine $\mathrm{P}$, eds. Standards in pancreatic surgery. Berlin, Heidelberg: Springer-Verlag 1990: 290-6.

47 Braganza JM. Pancreatic disease: a causality of hepatic 'detoxification'? Lancet 1983; ii: 1000-3.

48 Bordalo O, Bapista A, Dreiling D, Noronha M. Early pathomorphological pancreatic changes in chronic
alcoholism. In: Gyr KE, Singer MV, Sarles $\mathrm{H}$, eds. Pancreatitis concepts and classification. Exerpta Medica, Pancreatitis concepts and classification. Exerpta Medica, Elsevier.

49 Beger HG, Büchler M, Malfertheiner P, eds. Standards in pancreatic surgery. Berlin, Heidelberg: Springer-Verlag,

50 Malfertheiner P, Mayer D, Schiefer B, Büchler M, Ditschuneit $H$. Does inhibition of pancreatic secretion alleviate chronic pain in chronic pancreatitis? Gastroenterology 1992; 102 (suppl 2): A277.

51 Schmalz MJ, Soergel KH, Johanson JF. The effect of octreotide acetate, (sandostatin), on the pain of chronic pancreatitis. Gastroenterology 1992; 102 (suppl 2): A290.

52 Gullo L, Barbara L. Treatment of pancreatitis pseudocysts with octreotide. Lancet 1991; 338: 540-1.

53 Morali GA, Braverman DZ, Semesh D, Abrainoritz Z, Jacobsohn WZ. Successful treatment of pancreatic pseudocysts with a somatostatin analogue and cathete drainage. Am f Gastroenterol 1991; 86: 515-8.

54 Barkin JS, Reiner DK, Deutsch E. Sandostatin for contro of catheter drainage of pancreatic pseudocysts. Pancreas 1991; 6: 245-8.

55 Ellison EC, Garner WL, Mekhiian HS, O'Dorisio TM Carey LC. Successful treatment of pancreatic ascites with somatostatin analog SMS 201-995. Gastroenterology 1986 90: 1405 .

56 Gislason $\mathrm{H}$, Gronbech JE, Soreide O. Pancreatic ascites: treatment by continuous somatostatin infusion. $\mathrm{Am} \mathfrak{f}$ Gastroenterol 1991; 86: 519-21.

57 Büchler M, Friess H, Klempa I, et al. Role of octreotide in the prevention of postoperative complications following the prevention of postoperative complications followit

58 Delbert Kwan BA, Aufses AH. Short-term administration of SMS 201-995 in the management of an external of SMS 201-995 in the management of an external

59 Czyzyk A, Szadkowski M, Muszynski J. Reduced inhibitory effect of somatostatin on the exocrine function of the pancreas and on serum insulin levels in chronic relapsing pancreatitis. Horm Metabol Res 1984; 16: 155-9. 